\section{Concepções e percepções de fronteiras dos Professores da Educação Básica revelada por meio da foto-resposta (Extremo Oeste do Paraná - 2012)}

Resumo: O debate sobre fronteira ocorre com professores de Geografia atuantes na educação básica em 2012, por meio de entrevista e fotografia. Para o seu desenvolvimento priorizam-se quatro escolas públicas do município de Santa Terezinha de Itaipu-PR (região fronteiriça, inserida no espaço da Tríplice Fronteira - Brasil, Paraguai e Argentina), que apresentam maior demanda de alunos estrangeiros. Destacam-se nesta discussão dois momentos. Um deles refere-se à parte conceitual sobre fronteira e a política curricular do Estado. O outro, diz respeito ao uso da fotografia e entrevista e as concepções de fronteiras trazidas pelos professores para esta discussão. Como saldo importante da análise dessas duas trajetórias, o artigo busca evidenciar as contribuições e os limites postos ao sujeito de fronteira, o aluno brasiguaio, ao conceber-se o trabalho metodológico em sala de aula por meio de diferentes concepções de fronteira.

\section{Conceptions and perceptions of borders of the Basic Education Teachers revealed by photo response (Far West Paraná - 2012)}

\footnotetext{
Abstract: The debate over border occurs with Geography teachers acting in the basic education in 2012, through interviews and photography. To its development were prioritized four public schools in the municipality of Santa Terezinha de Itaipu - PR (border region, inserted in the space of Triple Border - Brazil, Paraguay and Argentina), that present the higher demand of foreign students. They stand out two moments in this discussion. One of them refers to the conceptual part about the border, and the curricular policy of the State. The other one relates to the use of photography and interview and the conceptions of borders brought by teachers for this discussion. As an important balance of the analysis of these two trajectories, the article seeks to highlight the contributions and the limits to the subject of the border, the Braziguayan student, when it conceiving the methodological work in the classroom through the different conceptions of border.
}

Margarete Frasson* Marli T. S. Schlosser**

* Mestranda em Geografia, Universidade do Oeste do Paraná(UNIOESTE)-Campus Francisco Beltrão.

** Professora do Curso de Geografia da Universidade Estadual do Oeste do Paraná - UNIOESTE - Campus de MarechalCândido Rondon/PR

\section{Palavras-chave:}

Fronteira; brasiguaio; fotoresposta.

\section{Key-Words:}

Border; Braziguayan; photo response. 
Das nove escolas, quatro são as que apresentam maiores demanda de alunos estrangeiros, as escolas municipais Monteiro Lobato e Olímpio Sprícigo (ensino fundamental I), e as escolas estaduais Dom Manoel Könner e Angelo Antônio Benedet (ensino fundamental II e ensino médio).

\footnotetext{
2 Alunos matriculados em escola brasileira, mas que passaram pela experiência escolar no Paraguai. Descendentes de brasileiros que moraram no Paraguai apresentam ou não, miscigenação étnica, mas trazem consigo uma nova identidade, que não é mais nem brasileira, nem paraguaia, e sim de migrante brasiguaio. $\mathrm{Na}$ escola vivem o processo de transição de uma cultura a outra.
}

Geografia Ensino \& Pesquisa, v. 18, n.2, p. 77-96, maio/ago. 2014

Concepções e percepções de fronteiras dos Professores da

Educação Básica revelada por meio da foto-resposta (Extremo Oeste do Paraná - 2012)

\section{Introdução}

Este artigo constitui parte da pesquisa de mestrado em educação e ensino de Geografia (2012-2013), "Alunos brasiguaios em movimento na Tríplice Fronteira”, desenvolvida junto a Universidade Estadual do Oeste do Paraná (UNIOESTE), campus Francisco Beltrão/PR, em escolas ${ }^{1}$ públicas no município de Santa Terezinha de Itaipu/PR com maior demanda de alunos estrangeiros.

A metodologia desta pesquisa inclui dois processos, que utilizados simultaneamente permitem notar acontecimentos e chegar a percepções que, por meio de outros recursos não se apreenderia, a foto-resposta e a entrevista em profundidade. A foto-resposta constitui-se em uma técnica empregada como forma de envolver o sujeito na construção da própria pesquisa. Entrega-se a ele um dos meios utilizados nessa produção, nesse caso específico, a câmera fotográfica, para que este responda por meio da representação fotográfica o significado de fronteira. A entrevista em profundidade forma-se por uma técnica dinâmica e flexível favorável a entender uma situação em que se está ou esteve envolvido. Essa modalidade é apropriada em situações onde há pouco conhecimento sobre o assunto ou mesmo quando necessários pontos de vista individuais.

As concepções de fronteira utilizadas no trabalho didático de Geografia podem mostrar ou ocultar elementos necessários à compreensão do espaço geográfico em seus limites e possibilidades. Por meio da fotografia como representação da fronteira, e entrevista, o professor demonstra a concepção de fronteira que trouxe para esta discussão. Por elas, analisam-se as concepções que possibilitam a compreensão deste espaço, em que estudam e vivem os alunos brasiguaios ${ }^{2}$. As fronteiras, pelas suas dinâmicas, criam áreas que se complementam. Portanto, ela não pode ser pensada como um absoluto, pois sua essência só pode ser apreendida a partir dela e da relação que mantém com outros espaços.

Nesse sentido, é preciso abrir para outras percepções de fronteira, para leitura do espaço, pois, “[...] o espaço é o mais interdisciplinar dos objetos concretos” (SANTOS, 2008b, p. 67). Dessa forma, pode-se pensá-lo “[...] como uma categoria autônoma [...]" (SANTOS, 2006, p. 16). Assim, a imagem fotográfica que captou os objetos concretos do espaço de fronteira, passa a ser o objeto de análise para pensá-la além do absoluto.

\section{Geografia, fronteira e o sujeito}

Desde o surgimento do Estado Nação e a constituição do ensino público, na idade moderna, a Geografia encontra-se no currículo escolar, e a fronteira faz parte do contexto de seu conteúdo.

Neste estudo utiliza-se da fronteira como categoria de interpretação teórica compreendendo-a como um conjunto que pressupõe a quantidade considerável de noções interligadas que constituem a própria base de seu discurso teórico. Para a sua compreensão conceitual, busca-se a noção de fronteira como divisa, limite, contato, contradição, área de transição. Perpassa-se pela fronteira do humano. Vale-se do espaço e território com o intuito de se chegar a uma sustentação teórica que fundamente essa reflexão.

A fronteira urbana entre as três cidades fronteiriças, Puerto Iguazú (AR), Ciudad del Este (PY) e Foz do Iguaçu (BR),próximo a esta, Santa Terezinha de Itaipu, constitui-se de vários centros. A área urbana abarca várias cidades, porém, não apresentam um núcleo em comum. Confirma-se a existência da fronteira, por não haver subordinação entre estes espaços urbanos, pois, cada cidade, individualmente, corresponde à margem de outro centro, localizado no interior dos diferentes Estados nacionais. Na sua origem, o conceito 
de fronteira "remete ao latim 'front', in front, as margens. [...] é, regra geral, um espaço definido pelo outro que está num centro (etnocêntrico), sendo, portanto, subordinado" (NOGUEIRA, 2007, p. 29).

A fronteira nada mais é do que o "[...] produto de uma divisão a que se atribuirá maior ou menor fundamento da 'realidade' segundo os elementos que ela reúne [...]" (BOURDIEU, 1989, p. 114-115). As formas, durante muito tempo, podem permanecer as mesmas na fronteira, porém, o fato é que cada momento histórico, cada elemento “[...] muda seu papel e a sua posição no sistema temporal e no sistema espacial e, a cada momento, o valor de cada qual deve ser tomado da sua relação com os demais elementos e com o todo" (SANTOS, 1985, p. 9).

A presença de imigrantes de diferentes nacionalidades (paraguaios, argentinos, brasileiros, libaneses, chineses, coreanos, japoneses, alemães, italianos, entre outros)presentes no Brasil, Paraguai e na Argentina faz com que os três países integrem-se num sistema próprio e peculiar dessa região fronteiriça. "Como a sociedade está sempre em movimento, a mesma paisagem, a mesma configuração territorial, nos oferecem, no transcurso histórico, espaços diferentes" (SANTOS, 2008a, p. 85). Esses migrantes constróem novos espaços, delimitando-os. Neste sentido, o território usado pela sociedade local rege as manifestações da vida social. No movimento da fronteira encontram-se os brasiguaios, sujeitos que buscam se territorializar no espaço fronteiriço.

Embora o limite possa "[...] designar o fim daquilo que mantém coesa uma unidade político-territorial” (MACHADO, 1998, p. 42), este, também se apresenta como “[...] sinal de contato entre dois ou mais territórios [...] os conceitos de limite e de fronteira interpenetram-se" (HISSA, 2006, p. 35). Para os brasiguaios os limites entre países impõem fronteiras que se manifestam na vida social.

Os limites territoriais das fronteiras entre Nações são postos, na maioria das vezes, por acordos e tratados entre dois ou mais países. Por meio destes acordos, são criadas as linhas que podem ser definidas por características naturais, ou artificiais. "[...] os limites aparecem como uma informação que estrutura o território” (RAFFESTIN, 2011, p 148). Para Kelsen (1998, p. 212).“[...] só um conhecimento jurídico, pode dar resposta à questão de saber segundo que critério se determina os limites ou fronteiras do espaço estadual, o que é que constitui a sua unidade".

Para Courlet (1996) a fronteira entendida como limite, não é uma barreira em um território, porém uma composição que procede de todo e qualquer ato nesse território. Segundo ele, a fronteira é imutável em sua existência estrutural e, é devido a ela que o capitalismo evolui, separa, diferencia, regula. Assim, constitui-se a fronteira em um "[...] fato econômico, financeiro, fiscal, diplomático, militar, além de político” (SANTOS, 2004, p. 179).

O território fundamenta a existência do limite e da fronteira. "Pode haver aproximação e distanciamento entre limites e fronteiras” (HISSA, 2006, p. 34). Se, por um lado, a fronteira parece representar o começo de tudo, onde exatamente tem-se a impressão que termina, o limite por outra parte, representa o fim, que situa a lógica do território. “[...] O território a cada momento se organiza de maneira diversa" (SANTOS, 2008a, p. 52), sendo que muitas reorganizações do espaço deram-se e continuam acontecendo. Desse modo, "o limite estimula a ideia sobre a distância e a separação, enquanto a fronteira movimenta a reflexão sobre o contato e a integração" (HISSA, 2006 p. 34). A ideia de Hissa complementa-se com a ponderação de Raffestin "O limite é, portanto, uma classe geral, um conjunto cuja fronteira é um subconjunto. [...] a fronteira é manipulada como um instrumento para comunicar uma ideologia" (RAFFESTIN, 2011, p. 148-149).

$\mathrm{Na}$ ideologia capistalista, Courlet (1996) em tempos de globalização, o capitalismo joga com a fronteira. $\mathrm{Na}$ destruição de uma fronteira, e no desaparecimento de uma pro-

Geografia Ensino \& Pesquisa, v. 18, n.2, p. 77-96, maio/ago. 2014.

Frasson, $M$.

ISSN 2236-4994 
teção, "Novas fronteiras se definem e permitem ação, estratégias coerentes e coordenadas que balizam e normalizam as diferenças, os desvios, para melhor administrá-los, ou mesmo eliminá-los" (COURLET, 1996, p. 2).

As fronteiras constituem-se em referências espaciais que se contrapõem a um centro, a uma centralidade construída a partir de um domínio. Fronteira e limite sofrem influência direta da concepção de poder, marcam campos de forças. Há que se considerar, para o brasiguaio, que vive uma territorialização precária, por estarem em constante mobilidade na fronteira, estes campos de forças exercem pressão em todos os setores de sua vida, criam similaridades e complexidades, estabelecem a diferença entre "nós" e os "outros". Para este grupo social,

[...] a fronteira de modo algum se reduz e se resume à fronteira geográfica. Ela é [...] fronteira da civilização (demarcada pela barbárie que nela se oculta), fronteira espacial, fronteira de culturas e visões de mundo, fronteira de etnias, fronteira da história e da historicidade do homem. E, sobretudo, fronteira do bumano. [...] É na fronteira que encontramos o humano no seu limite histórico (MARTINS, 2009, P. 11. grifo do autor).

A zona fronteiriça “[...] é uma zona híbrida, babélica, [...]. Em tal zona, são imensas as possibilidades de identificação e de criação cultural, todas igualmente superficiais e igualmente subvertíveis" (SANTOS, 1993, p. 49).

Neste sentido, “[...] a noção de limite é um dos componentes gerais de toda prática, não somente espacial". (RAFFESTIN, 2011, p. 137). Significa dizer que, para o aluno brasiguaio, ao conviver no espaço de contradição entre as duas culturas: a que ele traz consigo de outro país, e a que se apresenta no espaço de convivência da escola atual, onde está a fronteira, está o limite contraposto.

Para Martins(2009, p. 20) “[...] A fronteira tem sido, entre nós, um sujeito político", cria territorialidade que "[...] se manifesta em todas as escalas espaciais e sociais; ela é consubstancial a todas as relações e seria possível dizer que, de certa forma, é a 'face vivida' da 'face agida' do poder". (RAFFESTIN, 2011, p. 145).

Tendo em vista a premissa posta por Martins (2009) e Raffestin (2011) buscar a compreensão de como são trabalhadas as fronteiras pelos professores, pode permitir a formulação de um novo conceito de fronteira e a possibilidade de percepção de novas fronteiras que podem ser debatidas no trabalho metodológico em sala de aula na disciplina de Geografia e auxiliar o aluno "brasiguaio", aluno de fronteira em seu processo de transição na fronteira.

\section{As fronteiras na proposta curricular do Estado}

Geografia Ensino \& Pesquisa, v. 18, n.2, p. 77-96, maio/ago. 2014

Concepções e percepções de fronteiras dos Professores da

Educação Básica revelada por meio da foto-resposta (Extremo Oeste do Paraná - 2012)
O ensino da Geografia, ao participar da constituição/consolidação do Estado-Nação, separa o sujeito do objeto de conhecimento pelo conteúdo trabalhado. O currículo escolar, "[...] ao separá-los, faz uma opção pelo objeto do conhecimento, negando, por conseguinte, o sujeito". (VLACH, 1987, p. 49). Os professores apontam no currículo conteúdos sobre fronteira trabalhados em sala de aula que marcam a presença do Estado e do mercado. Duas entidades formais abstratas que pertencem também ao mundo da cultura (MARTINS, 2007). No ideário neoliberal, é incumbência do Estado buscar a eficiência e a equidade. Segundo esta política, dois conceitos fun- 
damentais (eficiência e equidade) são necessários à promoção do crescimento e desenvolvimento econômico. A direção que toma a sociedade nos planos econômico-social, ético-político, cultural e educacional, na atualidade, firma-se no ideário liberal. Sob esta ótica, a exclusão e a desigualdade são justificadas como necessárias à competitividade. O currículo contribui com tal exclusão, quando direciona o professor a trabalhar um conteúdo que o aluno não consegue relacionar ao seu cotidiano. Incentiva-se a individualidade, sob a égide da necessidade de um trabalhador flexível ${ }^{3}$ , adota-se, como princípio educativo, formar intelectuais/trabalhadores, os cidadãos/produtores, como um novo tipo de trabalhador para todos os setores da economia. Impede-se qualquer sentimento político-social por parte do aluno, quando se dissocia o ensino da sua existência.

O Estado brasileiro, sob o manto do desenvolvimento, programa e desenvolve políticas públicas sociais, visando ao interesse da classe social que detém o controle dos meios de produção e o poder político. O discurso "oficial" brasileiro em sintonia com as políticas mundiais adotadas em âmbitos social, econômico e cultural, na atualidade, para a área educacional, "[...] enfatiza que o papel da escola deve ser o de formar o 'cidadão' para atuar numa sociedade democrática e globalizada".JACOMELI, 2008, p. 3). Há uma contradição entre teoria e proposta efetiva, como aponta a professora Sebastiana, "[...] o livro didático em si, traz a diversidade [...], mas não trabalha o diferente. Ele aborda em termos de fronteira física, nem um momento, ele traz outro tipo de fronteira, ele traz a imagem, mas da fronteira física" (BENDO, Entrevista, nov. 2012). Ao trazer o conteúdo necessário ao entendimento de outras fronteiras, sem abordagem contundente e crítica, o livro didático cumprirá a função hegemônica da escola, como instituição necessária ao funcionamento da sociedade capitalista de produção.

A política curricular implantada na década de 1990, os Parâmetros Curriculares Nacionais (PCNs), documentos oficiais do Ministério da Educação e Cultura (MEC) para o ensino fundamental, adota a divisão dos conteúdos em atitudinais (valores e normas para o convívio social), procedimentais (os processos que se colocam em ação para alcançar as metas a que se propõe) e conceituais (construção das capacidades intelectuais para operar com representações que permitam organizar a realidade). O Estado do Paraná constrói as Diretrizes Curriculares da Educação Básica, que propõem o ensino dos conteúdos disciplinares através da organização por conteúdos estruturantes ${ }^{4}$, sendo os da Geografia assim compostos: Dimensão econômica, dimensão política, dimensão cultural e demográfica, e dimensão socioambiental do espaço geográfico.

José Gimeno Sacristán (1998, p. 109) define a política curricular como sendo

[...] um aspecto específico da política educativa, que estabelece a forma de selecionar, ordenar e mudar o currículo dentro do sistema educativo, tornando claro o poder e a autonomia que diferentes agentes tem sobre ele, intervindo, dessa forma, na distribuição do conhecimento dentro do sistema escolar e incidindo na prática educativa, enquanto apresenta o currículo a seus consumidores, ordena seus conteúdos e códigos de diferentes tipos(SACRISTÁN, 1998, p. 109).

A política educativa representada pelos PCNs a nível nacional e as DCEs (Diretrizes Curriculares Estaduais) no Paraná, construída por técnicos após a aprovação da Lei de Diretrizes e Bases, foi apresentada aos professores. Tal como no mercado, estes documentos chegam para serem consumidos, embora as Diretrizes Curriculares do Estado do Paraná, em seu processo de construção, aparentemente, tenham sido discutidas com professores, o material que chega até as escolas está distante do sujeito da escola pública. A proposta curricular do Paraná traz, em sua aparência, um discurso histórico crítico que seria condizente com os sujeitos a que se destina, contudo, ficou apenas no discurso. A costura realizada, os remendos postos no tecido curricular que chega à escola constituem-se como corte e limite, uma vez que o conteúdo a ser trabalhado atende à classe dominante. Forma e conteúdo negam o próprio discurso teórico, de modo que se estabelece a fronteira entre sujeito e conteúdo trabalhado.
3 O trabalhador que corresponde à intensificação da exploração do trabalho, seja pela velocidade da linha, pela integração da cadeia produtiva, pela geração de trabalho qualificado e flexível ou por meio do uso de maquinário automatizado e informatizado. Ao entendimento deste Artigo é um indivíduo que saiba viver o desemprego, gere novas formas, não capitalistas de produção,a exemplo dos que vivem na informalidade.

\footnotetext{
${ }^{4}$ De acordo com as DCE da Secretaria de Estado da Educação são saberes e conhecimentos de grande amplitude que identificam e organizam os campos de estudos de uma disciplina escolar, considerados fundamentais para a compreensão de seu objeto de estudo e ensino. A partir deles, derivam-se os conteúdos específicos, a serem trabalhados na relação de ensino e aprendizagem no cotidiano escolar.
}

Geografia Ensino \& Pesquisa, v. 18, n.2, p. 77-96, maio/ago. 2014.

Frasson, M.

ISSN 2236-4994 81 


\section{Uso da foto-resposta e entrevista para leitura da fronteira}

${ }^{5}$ No primeiro, a identidade do professor e a sua ligação com a Tríplice Fronteira; no segundo, a importância das fronteiras captadas pelas fotografias para o sujeito; no terceiro, buscou-se a percepção de novas fronteiras a partir das representações fotográficas.

${ }^{6}$ Priorizaram-se as entrevistas que trouxeram conteúdo e imagens que possibilitassem um panorama mais completo sobre a fronteira, de acordo com a fundamentação teórica, e que se pudesse refletir sobre a temática. Porém, evidenciase que todas as entrevistas foram utilizadas, mesmo que parcialmente.

Geografia Ensino \& Pesquisa, v. 18, n.2, p. 77-96, maio/ago. 2014

Concepções e percepções de fronteiras dos Professores da

Educação Básica revelada por meio da foto-resposta (Extremo Oeste do Paraná - 2012)
A paisagem demonstrada pela fotografia não reproduz o fato ali representado, mas o reconstrói, a partir de uma linguagem própria. A imagem fotográfica é, antes de tudo, "[...] uma representação a partir do real, segundo o olhar e a ideologia de seu autor. Assim, [...] os indícios se explicitam (materializam) mediante o sistema de representação fotográfica" (KOSSOY, 2004, p. 229, grifos do autor).

A pesquisa, por meio da entrevista e fotografia, constituiu-se em um processo de vários contatos. Somente após as fotos enviadas por e-mail, ou emprestadas para reprodução e reveladas, a entrevista foi agendada, deixando-se a critério do entrevistado a data, a hora e o local, ocorrendo na casa ou no local de trabalho do professor em sua hora atividade, ou em aula vaga.

Se a imagem, na Geografia, de um modo geral, "[...] sempre se viu relegada à condição de 'ilustração"' (KOSSOY, 2004, p. 224), a imagem captada pela fotografia foi utilizada nesta pesquisa como forma de dar respostas àquilo que Santos denomina de "[...] luta entre contrários, contrários que se chocam e criam uma nova realidade" (SANTOS, 2008a, p. 104), tão presentes em situação de fronteira. Levando-se em conta que "[...] a imagem pensada fora do seu contexto é pura abstração, seu significado é vazio" (KOSSOY, 2004, p.232), ao preparar o formulário para as entrevistas, procurou-se levantar questões que, por meio das fotografias, pudessem evidenciar a concepção de fronteira que o professor trouxe para a entrevista e, a partir da sua perspectiva, chegar a outras expressões de fronteira.

O questionário foi organizado em blocos ${ }^{5}$, que conduziram o olhar do entrevistado sobre a temática, analisando-a junto ao currículo, ao livro didático, à vivência do aluno, ao espaço da Tríplice Fronteira e ao ensino (trabalho metodológico em sala de aula).

O uso de fotos nas entrevistas comprova a ideia de Kossoy (2004, p. 232) "existe um conhecimento implícito nas fontes não verbais como a fotografia; descobrir os enigmas que guardam em seu silêncio é desvendar fatos que the são inerentes e que não se mostram".

Pela fotografia, o professor dá a resposta ao que é fronteira (foto-resposta, BOAL, 1977), analisa as imagens e "[...] percebe seus silêncios e decifra seus códigos" (RUBIM; OLIVEIRA, 2010, p. 11), para chegar a um "[...] processo de construção de realidades" (KOSSOY, 2004, p. 230, grifos do autor).

As doze entrevistas realizadas, correspondendo a noventa e dois por cento $(92 \%)$ dos professores efetivos de Geografia das escolas pesquisadas, geraram quarenta e oito imagens fotográficas, algumas mostrando os mesmos espaços. Para pensar a fronteira no contexto da Tríplice Fronteira (Foz do Iguaçu/BR, Puerto Iguazú/AR, Ciudad del Este/PY), com o professor de Geografia, por meio das concepções de fronteiras trazidas por ele, foram utilizadas cinco imagens ${ }^{6}$, contemplando cinquenta por cento $(50 \%)$ dos professores das escolas municipais e cinquenta por cento $(50 \%)$ das escolas estaduais.

No processo de criar e pensar: "O artista cria, e criando ele pensa tanto quanto [...] o filósofo" (FRANCASTEL, 1993, p. 5). Assim, entrevista e imagens levam o professor a pensar as fronteiras por meio do conhecimento e da sensibilidade, sendo possível "[...] identificar as posições éticas, estéticas e políticas que o indivíduo, como autor da obra, assume diante das lutas históricas do presente em que vive" (RUBIM; OLIVEIRA, 2010, p. 1) e a expressarem-se como "[...] sujeitos produtores de história e de saber" (RUBIM; OLIVEIRA, 2010, p. 2).

A questão a partir desta dinâmica é lidar com a diversidade de fronteiras apresentadas pelos professores. De acordo com cada uma delas, o território é identificado por uma espessura de densidade de relações diferentes, uma com o tecido espacial mais espesso e outras mais modestas. Constitui-se uma tarefa complexa compreender todas estas fronteiras pelas concepções que se utiliza o livro didático e currículo. Este processo pode levar muitas delas a desaparecerem enquanto fronteiras, impedindo a compreensão do espaço geográfico pela sua totalidade. Neste contexto o 
limite apresenta-se como componente geral da prática, não somente espacial, física, mas, política, diplomática, jurídica, fiscais, militar, financeira, econômica, social, entre outras.

Assim, no momento em que os professores começam a perceber outras fronteiras, a partir das registradas pelas imagens fotográficas, evidencia-se, “[...] a gente ouve falar, fronteira, fronteira, mas de um país para o outro, mas aí a gente vê que fronteira vai muito, além disso, então, tem muita coisa que se apresenta como fronteira" (IZÉ, Entrevista, nov. 2012), a exemplo "[...] das fronteiras sociais, que são muito evidentes" (BORGES, Entrevista, nov. 2012), “[...] não é somente o limite físico” (MACIEL DO ROSÁRIO, Entrevista, nov. 2012); foi quando "[...] comecei perceber as fronteiras que eu tenho em sala de aula" (GRIZ, Entrevista, nov. 2012). "Tem-se uma compreensão errônea de fronteira. A falta de consciência faz com que a gente compare. Temos que entender as diferenças e não ficar fazendo comparações" (OLIVEIRA, Entrevista, nov. 2012).

Estes posicionamentos revelam que a "paisagem é dialética" (MOREIRA, 1987, p.181), eles refletem [...] a complexidade da relação homem-mundo que, permeada pela relação homem-homem, gera uma sociedade espacializada na lógica das contradições dessas relações [...] (FERRAZ, 2009, p. 40).

Desse modo, a fotografia, como representação de fronteira mediada pela entrevista e contextualizada em espaço de fronteira vivido pelo professor, é que este concebe outras expressões e concepções de fronteira.

A imagem pensada fora do seu contexto é pura abstração, o seu significado é vazio. Portanto, na incursão pela teoria do conhecimento, abre-se lugar à necessária compreensão do ato de produzir conhecimento e de suas relações com o mundo da ciência.A Figura 1 demonstra este processo.

A velha maneira de utilizar a fotografia na ciência/disciplina de Geografia seria para ilustrar um fato ocorrido. Aqui, destina-se também a pensar as concepções de fronteira utilizadas no interior das escolas, pelos indícios que se materializam mediante o sistema de representação fotográfica. A entrevista conduz a contextualização da fotografia ao mesmo tempo em que é conduzida por ela. A fronteira de modo algum se reduz e resume-se à fronteira geográfica.

Figura 1 - Processo de leitura a partir da fotografia - Fronteira para o professor.

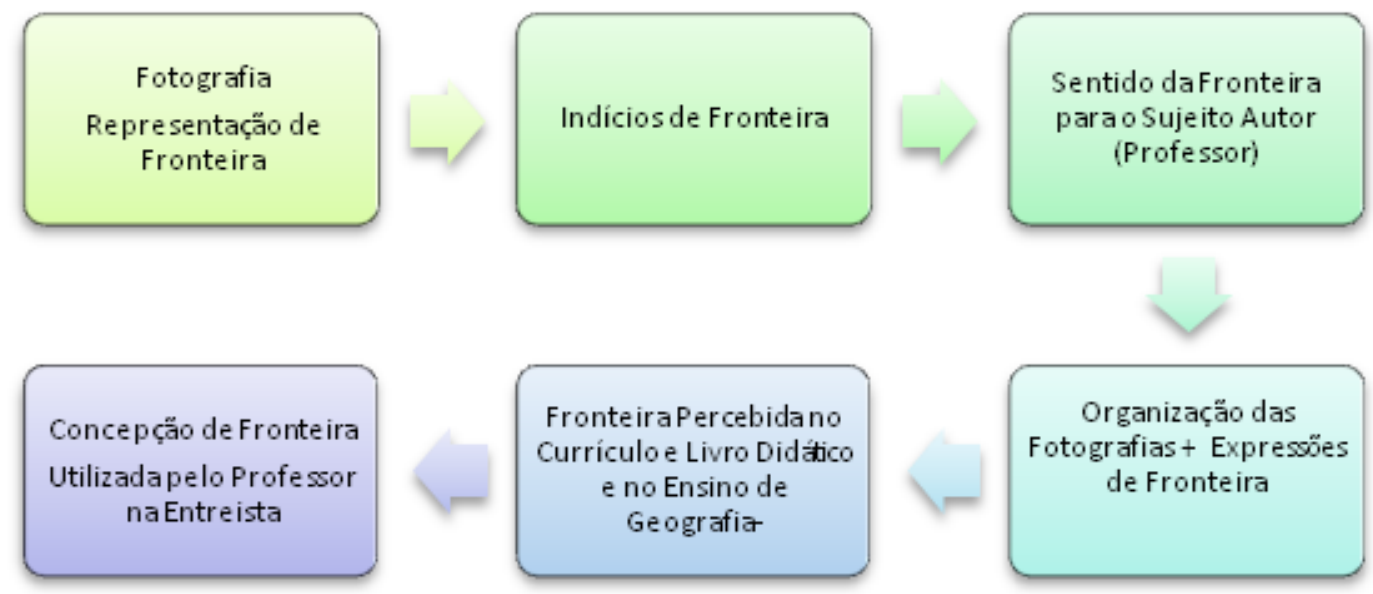

Análise daUtilização 


\section{Concepções de fronteiras políticas e naturais}

A observação da Imagem Fotográfica 1 (Figura 2) sem antes (origem)nem depois (conteúdo contextualizado), permite uma leitura limitada. Identificam-se nesta imagem, alguns elementos que evidenciam um espaço de clima frio pelas vestimentas das pessoas, o telhado inclinado das edificações, o solo sem vegetação. Não há a informação, se esta panorâmica está inserida em um local de altas latitudes, percebe-se apenas que o Sol não se mostra nesta paisagem e, pelo horizonte, o dia apresenta-se nublado. A imagem traz uma placa que, por meio dela, possibilita encontrar mais evidências.

Detendo-se à leitura da placa (Imagem Fotográfica 1), aí encontra-se um forte indício de fronteira, pelo que está escrito e a fotografia passa a ganhar significado. "CRUCE INTERNACIONAL 1 ra ANGOSTURA ESTRECHO DE MAGALLANES MANEJE CON PRECAUCIÓN VEHICULOS DESEMBARCANDO”. Trata-se de uma fronteira em um país que adota, como idioma, o espanhol. A primeira expressão, ou a primeira linha escrita na placa, passa mais um indício, é uma fronteira internacional, pois está se referindo à "travessia internacional". A outra identificação é que se trata do Estreito de Magalhães, que separa a Argentina do Chile. Pode-se perguntar: Em qual lado da Fronteira foi tirada esta foto? Se Angostura refere-se à cidade local, aí percebe-se que se está na Argentina e

7 Entre o continente sulamericano a norte; e a Terra do Fogo e cabo Horn, a sul.

${ }^{8}$ No Rio Grande do Sul/BR e Rivera/UY (fronteira seca).

9 A prioridade é estabelecida pelo professor, segundo critério que ele mesmo define, pode ser para ele, como cidadão ou como profissional ao utilizá-las como recurso didático em seu trabalho ou por apresentar algum valor afetivo, ou ainda por algum conteúdo específico considerado importante em sua trajetória de vida. não no Chile. Agora, "1 ra" ANGOSTURA, se este termo, "1 ra", significa a primeira cidade que se encontra do outro lado da fronteira, aí esta foto foi tirada no Chile.

Figura 2 - Estreito de Magalhães (Imagem Fotográfica 1).

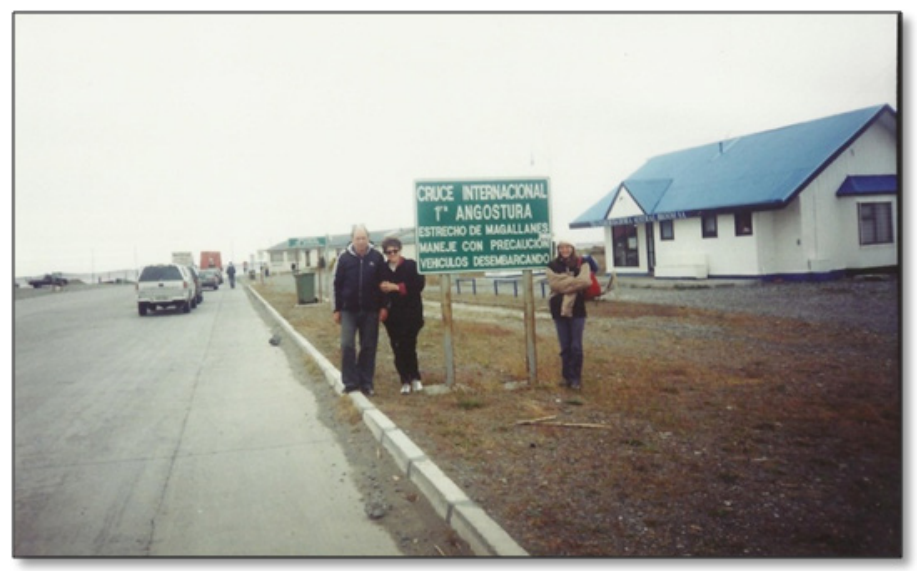

Fonte: fotografia de Lairce Terezinha Bosch Mogerstearn.

Motivo: "Porque foram os locais de fronteira próximos que eu visitei pessoalmente. Essa foi uma das fotos que eu tirei, estando nesses locais. Eu achei bem interessante essa do Estreito de Magalhães, onde nós estamos é do lado do continente" (MOGERSTEARN, Entrevista, nov.2012).

A Imagem Fotográfica 1, denominada por Estreito de Magalhães, faz parte de um conjunto de quatro imagens apresentadas como foto-resposta, dada ao que significa fronteira para a professora de Geografia, Lairce Terezinha Bosch Mogerstearn (Entrevista, nov. 2012). Ela, como autora da obra, justifica a sua escolha ao apresentar as quatro imagens fotográficas que simbolizam fronteira: Estreito de Magalhães ${ }^{7}$, Santana do Livramento ${ }^{8}$,rio da Prata e a fronteira entre Corumbá/BR e Porto Soares/BO. Essas imagens trazidas para o debate, organizadas, na ordem de prioridade9, por Mogerstearn (Entrevista, nov. 2012), segue como critério, a organização didática com que as utiliza em sala de aula para explicar as diferentes fronteiras aos alunos. São imagens que vêm carregadas de sentido para sua autora, pois foram captadas por ela estando nestes lugares, em férias, com a família. 
A fotografia colocada em primeiro lugar (Imagem Fotográfica 1) trata de uma viagem feita na companhia de parentes argentinos ao Estreito de Magalhães. Embora, na entrevista, ela deixe claro que conheça estes lugares de passagem, não viveu as geograficidades do local, o conhecimento agregado por ela vem carregado de sabor, de sentimento, ligado a sua historicidade. Um saber com sabor, percebido pelo entusiasmo com que fala dos lugares pelos quais passou, os detalhes que evidenciam as comparações entre lá e aqui, entre o que imaginava e o que encontrou no local. Esse mesmo entusiasmo pode-se conseguir do aluno brasiguaio dando-se a ele a oportunidade para expressar o que sabe sobre o espaço vivido para além do limite internacional de fronteira.

Estas fotografias constituem nesta discussão, as primeiras fronteiras. As segundas fronteiras, que a professora destaca a partir das fotografias, dizem respeito à fronteira cultural dando ênfase à língua. E a terceira fronteira, a dificuldade que o aluno brasiguaio tem em compreender o sistema educacional do Brasil que é diferente do sistema educacional do Paraguai. As três expressões de fronteira, demonstram que a fronteira nada mais é do que o produto de uma divisão a qual atribuirá menor ou maior fundamento da realidade segundo os elementos que ela reúne.

Ao ser indagada sobre como o currículo e o livro didático abordam o conteúdo fronteira, a entrevistada, por ser professora do fundamental II e ensino médio, salienta que, desde o sexto ano, trabalha-se com o conteúdo sobre fronteira, em muitos momentos, o conteúdo aparece, sem a denominação fronteira. Entre os vários conteúdos sobre fronteira menciona a América Platina, a Fronteira entre México e Estados Unidos, a ligação do Porto de Paranaguá a Assunção pela BR 277.

As fronteiras que a autora destas fotografias trouxe possibilitam colocar em evidência o histórico da Tríplice Fronteira Foz do Iguaçu/BR, Puerto Iguazú/AR, Ciudad del Este/PY.Com exceção da fronteira entre Santana do Livramento/BR e Rivera/UY, as demais estão ligadas às explorações realizadas na região da malha hidrográfica do rio da Prata na disputa por território e domínio comercial na Região. São fronteiras que "[...] vivem a fronteira com o espanhol. Automaticamente as pessoas falam a língua do outro" (MOGERSTEARN, Entrevista, nov. 2012), fazem parte da história dos alunos brasiguaios, que, como alunos desta fronteira, vivem "[...] a barreira da língua, porque uma coisa é ir ao Paraguai fazer compra e usar o espanhol [...]. Outra coisa é você usar a gramática deles" (MOGERSTEARN, Entrevista, nov. 2012). Estas fronteiras são trabalhadas [...] discutindo aqui, na nossa região, como é a fronteira, a gente discute as características daqui dando exemplo de outras fronteiras que tem no Brasil. (MOGERSTEARN,Entrevista, nov. 2012).

Após esta análise, chega-se ao entendimento que a concepção de fronteira posta em discussão por Mogerstearn (Entrevista, nov. 2012)trata-se de "limites e fronteiras políticas internacionais". De acordo com o grupo de pesquisa da Universidade Federal do Rio de Janeiro (grupo Retis) ${ }^{10}$ :as fronteiras, mesmo as chamadas naturais, são resultado de convenções (bilaterais) ou de imposição (unilateral).

Esta opção por discutir a fronteira política como se ela fosse natural, e deixar essa ideia fazer parte do currículo, tem um fundamento ideológico, pois faz parecer que as relações de fronteira também são naturais, oculta as contradições deste espaço.

Os tipos de fronteira e suas peculiaridades (DIETZ, 2008) concentram-se, sobretudo, nos casos entre Estados Unidos da América e México e sobre as da União Europeia. Quanto às fronteiras internacionais do Cone Sul, há escassez de estudos sistemáticos acerca dessas fronteiras.

A escola, através de seus procedimentos didáticos, conduzidos pelo currículo, prioriza a compreensão dos limites entre países em detrimento das fronteiras que se criam entre as nações e seus cidadãos pelo processo de acumulação capitalista, que se escondem por trás das concepções de fronteiras políticas. Utiliza as fronteiras próximas para com-
10 Disponível em http:// www.igeo.ufrj.br/fronteiras/ pesquisa/fronteira. Acesso em 30 de abril de 2013.

Geografia Ensino \& Pesquisa, v. 18, n.2, p. 77-96, maio/ago. 2014.

Frasson, $M$.

ISSN 2236-4994 85 
preender as fronteiras distantes. A ênfase deve ser dada à fronteira internacional em que está inserido o aluno, a fronteira próxima e não apenas na constatação da existência da linha limite. Bem como, chegar à leitura do espaço geográfico da sua fronteira, da que ele vive, para compreensão do seu lugar, pois é o lugar que permite o exercício da cidadania. No entanto, passa-se pela escassez de literatura a respeito, faz-se o trabalho pedagógico com fragmentos do cotidiano trazidos pelo professor e pelo aluno. Isso impede o acesso à construção do conhecimento necessário ao indivíduo como cidadão fronteiriço, neste estudo, o aluno brasiguaio. Um conhecimento que poderia auxiliá-lo a posicionar-se como sujeito da história.

A Imagem Fotográfica 2 (Figura 3), o Lago de Itaipu, é o material que, agora, apresenta-se aos olhos, pois a 'imagem' é sempre material, é sempre uma obra palpável aos olhos. [...] é a eles que elas destinam-se prioritariamente[...]. (OLIVEIRA JR, 2009, p. 19).

Figura 3 - Lago de Itaipu (Imagem Fotográfica 2).

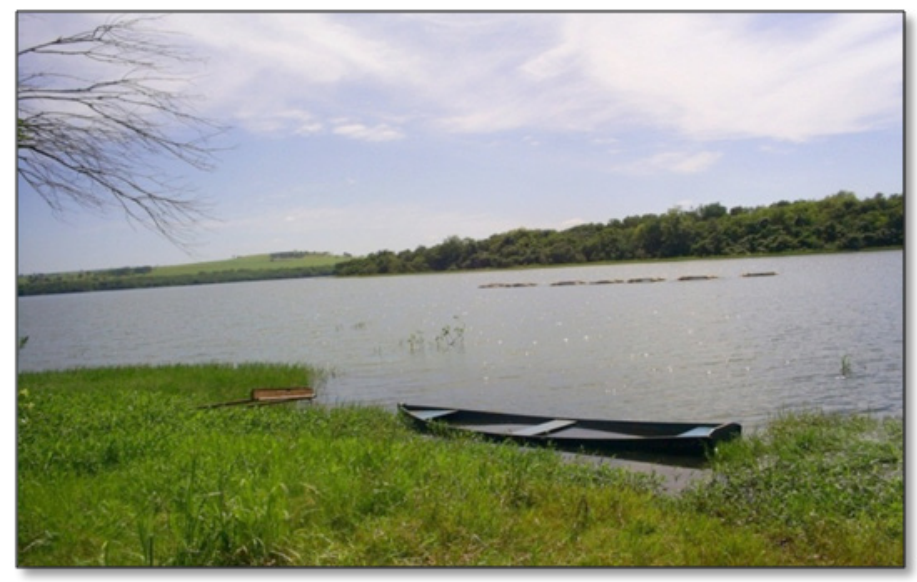

Fonte: fotografia de Ivan Gleison Borges.

${ }^{11}$ Em Santa Rosa do Ocoí São Miguel do Iguaçu.

Geografia Ensino \& Pesquisa, v. 18, n.2, p. 77-96, maio/ago. 2014

Concepções e percepções de fronteiras dos Professores da Educação Básica revelada por meio da foto-resposta (Extremo Oeste do Paraná - 2012)
Motivo:Geralmente, quando penso em fronteira, vem a minha cabeça os limites naturais, rios, montanhas, [...], mas, para mim, vem a minha cabeça os rios. Coloco essa como mais importante por ser a primeira ideia que vem a minha cabeça. Uma fronteira com água (BORGES, Entrevista, nov. 2012).

Analisando a paisagem que a foto apresenta, pela distância entre uma margem e outra, o que se vê é um braço do Lago de Itaipu. O Lago propriamente dito encontra-se à esquerda da imagem, é nesta direção que está localizado o Paraguai, indício de fronteira apresentado por esta imagem.No centro da imagem, encontram-se tanques de pesca, provavelmente da colônia de pescadores, cenário comum à região lindeira ao Lago de Itaipu. Com a construção da represa, mudou a rede hidrográfica da região, constituindo-se a foz de inúmeros rios em braço do Lago de Itaipu.

Porém, não será este o foco do olhar sobre esta imagem. Ela foi apresentada pelo professor Ivan Gleison Borges para representar a sua concepção de fronteira na entrevista realizada em novembro de 2012. As quatro imagens, representações de fronteira, se constituem, aqui, como que as primeiras fronteiras são organizadas por Borges (Entrevista, nov. 2012) na seguinte ordem: o Lago de Itaipu ${ }^{11}$, área de comércio em Ciudad del Este, a Zona Aduaneira entre Brasil e Argentina e, por último, as Cataratas do Iguaçu do lado brasileiro.

A imagem do Lago de Itaipu representa para o entrevistado os limites naturais de fronteira, por ser a primeira ideia que vem a sua cabeça ao referir-se a fronteira. É a fronteira com água. Quanto ao currículo e ao livro didático, observa com mais intensidade também a existência das fronteiras naturais, e ressalta que estas, permitem diferenciar e delimitar espaços"Até ali são as 
características de tal lugar, a partir dali começam as características de outro lugar [...]" (BORGES, Entrevista, nov. 2012).

A percepção das primeiras fronteiras vinculadas às características naturais conforme a posição do professor Ivan, na citação anterior, permanece nas segundas fronteiras, ou fronteiras de segunda ordem, que também apontam fronteiras ligadas a elementos naturais, qual sejam fronteiras secas; fronteiras com montanhas.E as terceiras fronteiras, ele aponta as fronteiras étnicas e sociais. É oportuno expressar, aqui, a visão das fronteiras étnicas e sociais que o professor Ivan apresenta como terceira fronteira, pois não se constitui um caso isolado, outros professores também se posicionaram de forma semelhante ao final da entrevista quando se questiona: "Teria mais alguma observação a fazer sobre essa temática: 'fronteira"'?

[...] Agora (com a entrevista), me veio várias ideias de fronteiras que eu não tinha pensado antes, essas fronteiras sociais, são muito evidentes [...], nós temos aqui alunos vieram de vários lugares, não só fronteiras de países, mas fronteiras sociais também, alguns são discriminados [...] (BORGES, Entrevista, nov. 2012).

O entrevistado cita, como terceira fronteira, a fronteira social. Assim, fronteira não é somente marcos de delimitação fixado no território físico. O limite do currículo desenvolvido representa a lógica que a classe hegemônica quer para os subalternos no uso do território, que estes compreendam a condição social e econômica de desvalidos como se isso fosse natural.

O uso somente da concepção de fronteira física, natural constitui o currículo como limite por passar a ideia de fronteira como um processo natural. Neste processo, o espaço geográfico em suas relações e inter-relações também se apresenta como se fosse natural, oculta outras percepções de fronteiras necessárias para a conquista da cidadania pelo sujeito, sendo, no caso do presente estudo, ao sujeito brasiguaio.

\section{Concepções de fronteiras políticas e naturais}

A Imagem Fotográfica 3 foi apresentada por quatro professores como foto-resposta sobre a temática fronteira. Trata-se de uma panorâmica rica em detalhes do ponto de vista geográfico. Mesmo que se dissesse o que se vê nesta paisagem, não se conseguiria dizer o que ela representa no contexto de suas relações e inter-relações, como espaço geográfico de fronteira. Ao trazerem esta imagem para a discussão, apresentam-na como a existência da fronteira entre três países, cujo limite geográfico, é dado por elementos naturais ${ }^{12}$, os rios Iguaçu e Paraná, Assim, percebe-se a evidência de fronteira no significado de sua representação.

O significado individual atribuído à Imagem Fotográfica 3 (Figura 4) aparece no momento em que o entrevistado organiza as fotografias por uma ordem de prioridade estabelecida por ele próprio. Assim, a professora Beata Aparecida Reisdorfer de Oliveira coloca a imagem do Marco das Três Fronteiras em terceiro lugar, o professor Paulo Cézar de Moura e a professora Maristela Ferreira colocam-na em segundo, enquanto a professora Rejane Egídia Lucca aponta-a em primeiro lugar.

A ordem de importância das imagens fotográficas para Lucca (Entrevista, nov. 2012) fica assim construída: Marco das Três Fronteiras(Imagem Fotográfica3), Lago de Itaipu, Placa que demarca o limite entre municípios e o Cemitério. Quando indagada sobre esta ordem, a professora justifica: "organizei o espaço do mais distante (amplo) para o mais próximo. Do país, Estado, município, lugar" (LUCCA, Entrevista, nov. 2012). Ela expressa o sentido destas imagens ao comentar as diferenças entre limites, fronteiras e divisa. Segundo ela "utilizamos os três termos com o mesmo significado" (LUCCA,
${ }^{12}$ Visão de fronteira que traz o livro didático e mais apontada pelos professores.
Geografia Ensino \& Pesquisa, v. 18, n.2, p. 77-96, maio/ago. 2014.

Frasson, M.

ISSN 2236-4994 
Entrevista, nov. 2012). Traz a diferença, quando analisa a fotografia do cemitério, espaço dividido, entre a plantação de soja e os túmulos, por um muro, o qual representa uma divisa. Mas "trouxe a imagem como fronteira, por perceber a fronteira entre um espaço agrícola, rural de outro espaço, que não é a cidade, mas um território com uma utilização específica, diferente do espaço agrícola" (LUCCA, Entrevista, nov. 2012). Percebe-se neste caso que os conceitos de limites e fronteiras interpenetram-se. As linhas divisórias implicam o estabelecimento do limite, e estes, aparecem como uma informação que estrutura o "território", cuja integridade territorial a partir dos limites, passa a ser garantida. Assim, O território fundamenta a existência do limite e da fronteira.

Figura 4 - Marco das Fronteiras (Imagem Fotográfica 3).

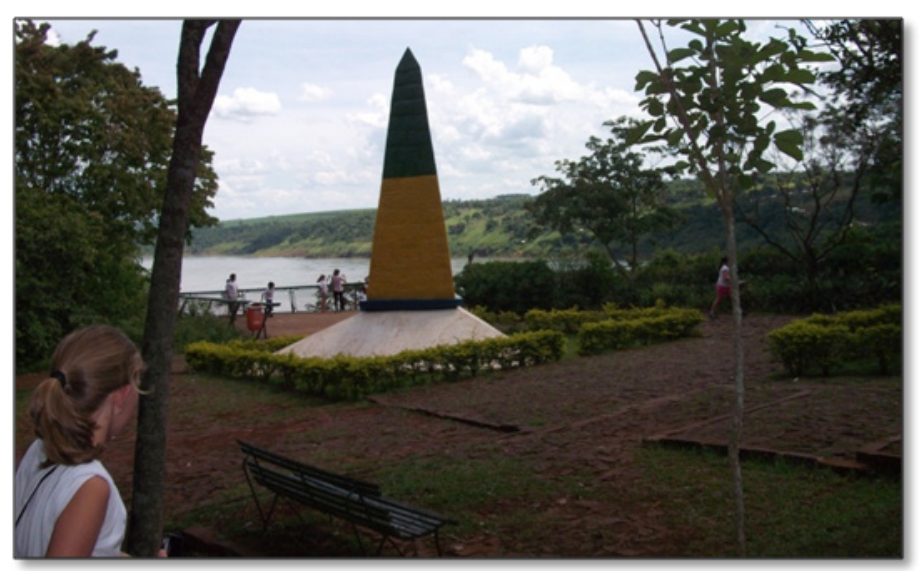

Fonte: fotografia de Rejane Egídia Lucca

Motivo: "Eu acho interessante esse marco em nossa região porque representa a divisa entre o Paraguai, Argentina e o Brasil" (LUCCA, Entrevista, nov.2012). "Para os alunos entenderem que aqui, nessa região, nós temos três países, que estes países estão bem próximos uns dos outros" (OLIVEIRA, Entrevista, nov.2012). "Porque representa o ponto de fronteira entre três países, não é muito comum termos uma fronteira entre três países" (MOURA, Entrevista, nov.2012). "Temos o encontro dos rios e, em cada margem, temos um país diferente, o Brasil, o Paraguai e a Argentina” (FERREIRA, Entrevista, nov.2012).

Limites e fronteiras, ao representar o fim e o início de uma jurisdição estatal, estabelecem os limites da cidadania, uma vez que os sujeitos não só se confrontam com os controles físicos e legais do limite político entre os países, mas também com limites culturais e simbólicos, além do limite físico entre dois territórios. Neste sentido, o lugar onde está construído o cemitério, se em países diferentes, pode apresentar uma relação também diferente com os sujeitos que aí vivem, demonstrando traços de identidade do "eu" e do "outro".

A partir das fotos do Marco das Três Fronteiras, Lago de Itaipu, Placa que demarca o limite entre municípios e o Cemitério, Lucca (Entrevista, nov. 2012), identifica outras fronteiras que se criam a partir das percebidas e captadas pela sua câmera fotográfica, fronteira da parte administrativa, empresas, de preços de terras. Exemplifica:

Geografia Ensino \& Pesquisa, v. 18, n.2, p. 77-96, maio/ago. 2014

Concepções e percepções de fronteiras dos Professores da Educação Básica revelada por meio da foto-resposta (Extremo Oeste do Paraná - 2012)
[...] num local, a terra pode ser mais valorizada do que um município que se encontra nas proximidades. Um município pode ter rede de esgoto e outro não, embora façam divisa, chega ali no limite do município, a rede de esgoto acaba. (LUCCA, Entrevista, nov. 2012).

As terceiras fronteiras, para ela, constituem "os lugares diferentes que eles (alunos) moram, uns têm bem mais condições financeiras que os outros; a de costumes o que eles tem na casa costumes que eles trazem". 
Lucca (Entrevista, nov. 2012) aponta outras expressões de fronteiraspercebidas na Tríplice Fronteira: “[...] empresas diferentes, línguas diferentes, valor monetário diferente, por exemplo, aqui, nós trabalhamos com o real. O Paraguai trabalha com dólar, real, guarani" (LUCCA, Entrevista, nov. 2012). Neste sentido, as evidências conduzem a uma utilização de concepção de fronteira ligada às fronteiras econômicas.

Esta concepção de fronteira pode permitir a compreensão da sociedade capitalista neoliberal, pois, de acordo com Moreira (2006, p. 111),"Do mercado vem a lógica das relações e a valoração das coisas. [...] vem a essência da linha que costura o pensamento geográfico em sua afirmação do espaço [...]" Assim, é necessário compreender o papel do espaço na sociedade, tendo em vista a compreensão desta sociedade. Nesta lógica, o lugar ocupado pelo sujeito no território interfere em sua cidadania, Santos (2006, p. 81) afirma que:'[...] a possibilidade de ser mais ou menos cidadão depende, em larga proporção, do ponto do território onde se está".

Pela ótica de Santos (2006), analisa-se a condição do sujeito brasiguaio, que pode apresentar condições melhores que o sujeito brasileiro, no entanto, por ter habitado em território paraguaio, é visto por brasileiros como menos cidadão. Neste contexto, ao aluno brasiguaio, é mais conveniente esconder a sua origem do que ser considerado menos cidadão aos olhos de alguns brasileiros, por ter morado no Paraguai.De acordo com Squinelo (2011, p. 19), há anos prevalecem relações estereotipadas entre Brasil e Paraguai, “[...] estereótipos [...] carregados de jargões e juízos de valor que não correspondem às inúmeras tentativas de aproximação e conhecimento do 'eu' e do 'outro', nesse caso Brasil e Paraguai, mutuamente".

A concepção de fronteira econômica utilizada na lógica do pensamento de Moreira e Santos (2006), acrescida da coesão entre objetivos, conteúdos e método, quando estabelecidos no currículo, pode permitir que se concretize o processo de compreensão do espaço de fronteira e do papel deste espaço na sociedade fronteiriça.

Mireily Aparecida Tomazoli de Oliveira, professora do ensino fundamental I, instiga outro olhar sobre a Tríplice Fronteira, quando disponibiliza, durante a entrevista em novembro de 2012, quatro imagens fotográficas. Foto-resposta, dada como representação de fronteira na seguinte ordem: a mesquita (Imagem Fotográfica 4) (Figura 5), o computador, a aduana entre Brasil e Paraguai, do lado paraguaio, e o rádio.

Figura 5 - Mesquita (Imagem Fotográfica 4).

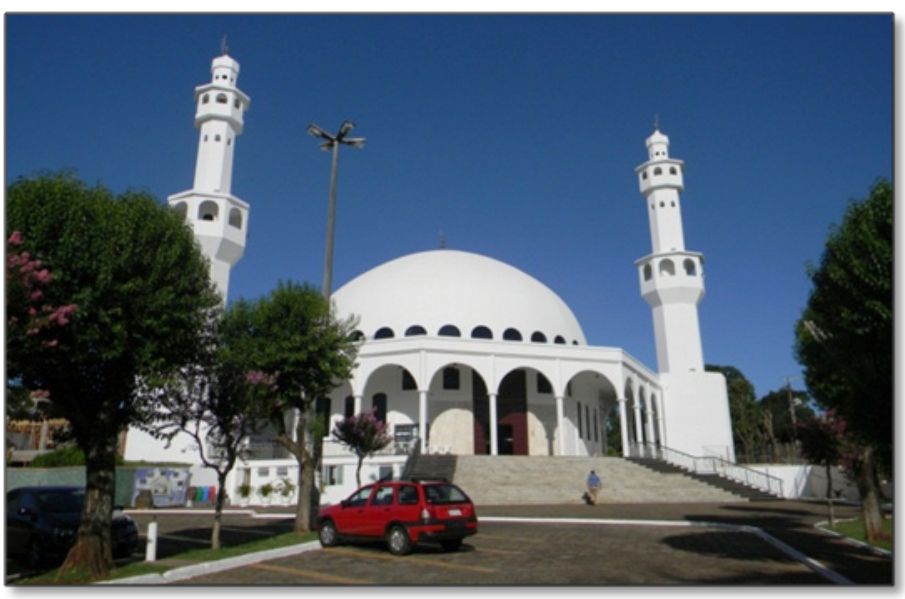

Fonte: fotografia de Mireily Aparecida Tomazoli de Oliveira.

Geografia Ensino \& Pesquisa, v. 18, n.2, p. 77-96, maio/ago. 2014.

Frasson, $\mathrm{M}$

Motivo: Representa os diferentes povos e culturas da Triplice Fronteira, "Não pelo povo árabe, aqui, na fronteira, mas é uma forma de representar todas as outras culturas, da nossa fronteira, principalmente Foz do Iguacu, Paraguai e Argentina, e outrospovos de outras partes do mundo” (OLIV EIRA, Entrevista, nov. 2012). 
13 IBGE. Estimativa. Jul. 2012. Disponível em: $<$ http://www.pmfi.pr.gov. br/conteudo/722/747/ Populacao $>$. Acesso em: 11 jul. 2013
Geografia Ensino \& Pesquisa, v. 18, n.2, p. 77-96, maio/ago. 2014

Concepções e percepções de fronteiras dos Professores da

Educação Básica revelada por meio da foto-resposta (Extremo Oeste do Paraná - 2012)
Observar a Imagem Fotográfica 4, foto da mesquita, colocada em primeiro lugar na ordem de prioridade estabelecida pela professora, pode representar apenas um traço cultural na paisagem. O espaço de fronteira não se mostra pela imagem. "O significado mais profundo da imagem não se encontra necessariamente explícito. O significado é imaterial; jamais foi ou virá a ser um assunto visível, passível de ser registrado fotograficamente" (KOSSOY, 2003, p. 117).

No entanto, a fronteira começa a fazer-se presente pelas relações que ali se estabelecem. Sobre isso, Oliveira (Entrevista, nov. 2012) comenta: "eu fui trabalhar quando mocinha ainda, na casa de libaneses, eu não sabia o que era o Líbano, Turquia, a gente começou a conviver com eles, eu comecei a olhar no mapa. O que faz eles virem para cá?”

Ao evidenciar a representação de fronteira pelas relações que se estabelecem, surge o sentido desta imagem para a autora da fotografia. A imagem de fronteira tem relação com a experiência vivida pela professora, no contato com povos que praticam a religião muçulmana. Outro aspecto a observar é que ao buscarem-se as razões que trouxeram estes migrantes a ocuparem este território formando novas territorialidades no lugar, perpassa-se por compreender os fatos que ocorreram no espaço-tempo deles.

A mesma dinâmica pode ser aplicada aos alunos brasiguaios, ao que supõe se possa encontrar no cerne desta mobilidade populacional, o Estado e o mercado, como regedores e formadores destas novas estruturas de fronteiras.

A partir das quatro imagens de fronteira (mesquita, computador, aduana e o rádio), denominadas de primeiras fronteiras, ela chega às segundas fronteiras, que identifica como "Medo do novo, de enfrentar os desafios" (OLIVEIRA, Entrevista,nov. 2012), e à terceira fronteira a que os aluno brasiguaios vivem, no processo de transição de um país ao outro, e fala disso com propriedade por ter vivido situação semelhante quando criança, quando foi morar no Paraguai e lá estudou. Por esta razão, acredita que, [... eles aprendem lá, é uma cultura, uns costumes. Chega aqui, são outros. É outro modo de pensar. (OLIVEIRA, Entrevista, nov. 2012). São fronteiras que de acordo com Santos (2006), acontecem através do processo global de mudanças que ocorrem no mundo.

\footnotetext{
O surgimento de numerosos Estados nacionais, a criação de organismos supranacionais, a entrada em cena da informação e do consumo como denominador comum universal, tudo isso trabalha para facilitar [...] as técnicas baseadas na informação e que iriam revolucionar doravante a economia e a política, antes de incluir a cultura no processo global das mudanças(SANTOS, 2006, p. 124).
}

O processo global das mudanças está presente na Tríplice Fronteira, ao evidenciar-se que a cidade de "Foz do Iguaçu abriga cerca de 80 das 192 nacionalidades"13 existentes no mundo, as quais são representadas pela fronteira materializada pela fotografia da Mesquita. O comportamento destas pessoas inseridas "em um dado contexto social, agindo, interagindo e relacionando-se diretamente com as estruturas. As ações, [...] em função destas estruturas sociais, [...] são moldadas e molda" (CREUZ, 2010, p. 40) aqueles com os quais se relacionam. Isso demonstra que, neste momento, nesta região, encontra-se um intenso "processo de hibridações, desterritorializações, descentramentos e reorganizações" (MONTIEL, 2003, p. 19).

A prática cotidiana de Oliveira (Entrevista, nov. 2012) contém elementos deste processo de hibridações, “[...] a gente passa a comer determinados pratos, a aprender esses costumes. Como o Shawarma. um exemplo. [...] a gente faz em casa os pratos que são originários daquela localidade".

Pela experiência e contato com elementos do espaço em suas relações e inter-relações que ultrapassam os limites da fronteira nacional, Oliveira (2012) percebe os limites postos no currículo e livro didático ao abordar a problemática fronteira quando destaca 
que o "currículo prevê várias abordagens de fronteiras [...]. As fronteiras em si, basicamente ele prevê trabalhar um pouquinho em cada ano. No livro didático, é mínimo o conteúdo sobre fronteira" (OLIVEIRA, Entrevista, nov. 2012).

Contudo, a fronteira, de modo algum, resume-se à fronteira física e política, ela é fronteira espacial, de cultura, de visões de mundo, de etnias, da história e da historicidade do homem, entre outras. A partir disso, compreende-se que a concepção de fronteira, apresentada por Oliveira (Entrevista, nov. 2012), constitui-se em fronteiras culturais e étnicas que se formam pelas relações que ocorrem na Tríplice Fronteira, devido à diversidade cultural a que ela está submetida, influenciando os espaços distantes e sendo influenciada por eles, pelas redes sociais que se formam entre o lugar e o local de origem dos migrantes, constituindo-se as mais diversas fronteiras.

De acordo com Santos (2008b, p. 52), “[...] qualquer parte do globo ganha nova conotação, tornando-se cada vez mais aberta, mais vulnerável às influências exógenas. [...] Não há, pois, como considerar a região como autônoma”. As influências podem ser intensificadas pelas outras representações de fronteira, o computador, a aduana e o rádio que permitem diferentes contatos entre as pessoas. O que deixa visualizar as ligações desta fronteira com outras partes do mundo, com outros territórios, através das redes sociais, conforme Arruda “a constituição de 'redes sociais' têm a função de ligar o país, em alguns casos, até a região de origem dos migrantes, com o país e a região em que se estabelecem"(ARRUDA, 2007, p. 48).

Para a Oliveiracom o uso do computador se rompe as fronteiras, com quem a gente não convive diariamente. (OLIVEIRA, Entrevista, nov. 2012). Neste sentido, o lugar convive com o espaço global, interagindo e também influenciando um ao outro. Esta influência precisa tornar-se visível ao olhar da escola sobre a fronteira, por estar situada em espaço que sofre interferência de diferentes espaços do mundo. O aluno brasiguaio é apenas um aspecto desta fronteira e, ainda assim, ele utiliza a invisibilidade para sobreviver no espaço da escola, o que demonstra que a fronteira, em suas contradições, não faz parte do cotidiano das instituições escolares em seus processos pedagógicos.

Para Gonçalves (2010, p. 14), “o lugar é orgânico, comunicacional e marcado por uma ordem que funda a escala do cotidiano". O lugar na fronteira não tem limites, as fronteiras do lugar em espaço de fronteira, são estabelecidas pelo próprio sujeito ou, então, os limites internacionais para o sujeito não existem, quando os dois lados da fronteira simultaneamente constituem-se em lugar. Faz sentido quando a professora Claudimery diz que "Os pais dos alunos do Paraguai, que fazem essa rota (entre Santa Terezinha de Itaipu/BR e localidades do Paraguai), não percebem que têm essa fronteira entre um país e outro" (IZÉ, Entrevista, nov. 2012).

Assim, o espaço da Tríplice Fronteira apresenta-se de forma complexa e contraditória, dificultando a percepção do que é interno e do que é externo. A cada fato vivido pelo sujeito integrante da população que vive nesta fronteira, um mesmo espaço pode ter a conotação de lugar, região, território e paisagem, ser interno e externo como também todos ao mesmo tempo. Encontram-se agindo sobre este espaço, forças difíceis de serem percebidas, mas que podem ser entendidas e percebidas pelo trabalho metodológico em Geografia com a concepção de fronteira cultural e étnica, no sentido de perceber o "ser humano" neste contexto.

De acordo com este pensamento, inserir, no aprendizado metodológico da escola, a prática existencial desta fronteira constitui-se em um grande desafio para a educação básica. Este desafio intensifica-se quando se leva em conta que, na sociedade capitalista neoliberal, há, no interior das escolas, via currículo e livro didático, um controle do pensamento do ser humano, fazendo com que a maioria tenha o mesmo modo de ver o mundo, impedindo que as possibilidades e limites mostrem-se aos sujeitos subalternos, o que se

Geografia Ensino \& Pesquisa, v. 18, n.2, p. 77-96, maio/ago. 2014.

Frasson, M. 
${ }^{14} 50 \mathrm{~km}$ no Paraguai e $150 \mathrm{~km}$ no Brasil.

15 São brasileiros e descendentes (peões, arrendatários, meeiros, pequenos proprietários de terra descapitalizados), cuja mão de obra foi utilizada pelo processo de modernização agrícola no Oeste paranaense (BR) direcionado (F LE I S C H F R E S SER, 1998) pelo Estado através de medidas de política econômica no processo de "limpeza dos terrenos", para, posteriormente, o "capital" fazer uso das inovações químicas e mecânicas em seu processo de produção. No Paraguai desempenharam esse mesmo papel. Nesta pesquisa, compreendidos conforme Fabrini (2011), como um grupo social que possui precário domínio sobre o espaço.

${ }^{16}$ Por exemplo, o brasiguaio não é mais útil no Paraguai para o sistema capitalista. Este brasiguaio, através de mecanismos, é atraído para o Brasil que oferece certos atendimentos através de políticas públicas (escola, saúde.), sendo que, para isso, ao Brasil é fornecido empréstimo pelo Banco Mundial, processo que convalida a exploração das riquezas naturais do Brasil para exportação com o intuito de gerar divisas para pagar a dívida. Hoje, ao sistema capitalista não existe nem limites e nem fronteiras.

Geografia Ensino \& Pesquisa, v. 18, n.2, p. 77-96, maio/ago. 2014

Concepções e percepções de fronteiras dos Professores da Educação Básica revelada por meio da foto-resposta (Extremo Oeste do Paraná - 2012) comprova quando a escola, através do currículo, nega o que os alunos brasiguaios sabem sobre o espaço de onde vieram. O jogo de forças que atua em área de fronteira é despercebido pela escola, pois as relações e as representações simbólicas que compõem os territórios, enquanto Estado-Nação, têm o seu significado oculto pela ação do currículo que impõe ao professor um conteúdo a ser desenvolvido na sala de aula que não condiz com a existência efetiva do espaço em que está inserido, o espaço da fronteira e de seus sujeitos.

Ao referir-se às diferenças entre o conceito de limite e fronteira, Martin (1997) evidencia "que o limite é reconhecido como linha, e não pode, portanto, ser habitada, ao contrário da fronteira, que ocupa uma faixa, constitui uma zona, muitas vezes bastante povoada onde os habitantes de Estados vizinhos podem desenvolver diferentes intercâmbios" (MARTIN 1997, p. 47). As quatro imagens fotográficas que representam a fronteira para a professora Sebastiana Lopes de Miranda Bendo, que trabalha com o ensino fundamental I e II, estão situadas na faixa de fronteira ${ }^{14}$.

Após pensar por vários instantes e ficar em dúvida ao arrumar a posição das imagens, a professora disponibiliza-as da seguinte maneira: primeira, alunos em sala de aula, ela justifica a escolha "Porque atendo crianças que vem de lá. (Paraguai). Nesta turma, há vários deles" (BENDO, Entrevista, nov. 2012), a segunda traz alunos de diferentes séries na hora do intervalo, a terceira mostra uma imagem de Ciudad del Este e a quarta destaca a Mesquita. Estas fotografias representam as primeiras fronteiras. Ao concluir o arranjo das fotos, ela analisa-as e afirma: "Eu olho para isso (as quatro fotos), tem diferenças enormes, diferenças religiosas, étnicas, culturais, [...]. Na sala de aula, todas essas fronteiras acabam se desfazendo" (BENDO, Entrevista, nov. 2012). De acordo com Santos: "A zona fronteiriça, tal como a descoberta, é uma metáfora que ajuda o pensamento a transmutar-se em relações sociais e políticas" (SANTOS, 1993, p. 51).

A fotografia tirada e apresentada como imagem principal para o debate por Sebastiana Lopes de Miranda Bendocontinha imagens de alunos em sala de aula, menores de idade. Por este motivo não foi disponibilizada. Sebastiana escolhe esta imagem pelo fato de atender alunos que vem do Paraguai e nessa foto há vários deles. Ao visualizar a fotografia que seria a Imagem Fotográfica 5, consegue-se identificar nela vários alunos já conhecidos por fazerem parte desta pesquisa, os quais pertencem a famílias de brasiguaios ${ }^{15}$.

A professora cita, como segunda fronteira, o conhecimento e a diversidade e, ao expor esta fronteira, ela desabafa: "Eles mesmos falam que o conhecimento que tiveram no Paraguai não vale. Não vale por que são brasiguaios? Ou por que aqui não é valorizado?”, (BENDO, Entrevista, nov. 2012).

A respeito desta problemática posta por Bendo (Entrevista, nov. 2012), pode-se afirmar que está ligada a diferentes fatores: a) ao encontro de sistemas educacionais que tentam ser "inclusivos", em contextos sociais "excludentes"; b) ao princípio da igualdade que, na fronteira, quando adotado, como prática pedagógica, mais exclui do que agrega o aluno ao sistema educacional e, consequentemente, à sociedade; c) estes dois países (Brasil e Paraguai) vivem historicidades desencontradas, isto é, momento de um sistema social e econômico representando estágios diferentes na economia, e, em decorrência, a educação na escola também se apresenta de forma diferente; d) ao capital que se utiliza do Bloco Econômico para realocar os elementos na fronteira de forma a excluir do espaço o elemento (humano) que está sendo desnecessário e coloca-o em outro que ainda possa gerar algumas formas de acumulação de capital para o sistema ${ }^{16}$, para que isso ocorra, vende a imagem que, no outro espaço, a educação apresenta-se com maior qualidade.

A terceira fronteira encontra-se na falta de interesse pelo conteúdo de Geografia. "Quando tento tornar interessante o conteúdo através de um filme, imagem; levo a campo, com desenhos [...] Quando se mostra pra eles [...] que eles podem fazer a diferença no lugar onde eles moram, aí parece que fica um pouquinho mais interessante" (BENDO, Entre- 
vista, nov. 2012). Quanto ao currículo, a fronteira, apontada está na diversidade. O livro didático,em si, traz a diversidade [...], mas não trabalha o diferente [...], nem um momento, ele traz outro tipo de fronteira(BENDO, Entrevista, nov. 2012).

Assim, chega-se à constatação de que a concepção de fronteira, que Bendo (Entrevista, nov. 2012) trouxe para a entrevista, trata-se de Fronteira social que ocorre em situação de fronteira marcada pelos processos de instalação do capitalismo no espaço.Ao instalarem-se no Paraguai, as famílias de brasileiros fizeram parte como frente pioneira e também como frente de expansão naquele país, ao retornarem, o capitalismo já havia se instalado na região Oeste paranaense (Brasil), ocorre que os grupos sociais brasileiros e paraguaios vivem temporalidades distintas, provocando esta situação de fronteira social, embora sejam expressões do mesmo processo.

Conforme Martins (2009):
A distinção entre frente pioneira e frente de expansão [...] É um instrumento útil quando as duas concepçóes são trabalhadas na sua unidade, quando destaca a temporalidade própria da situação de cada grupo social da fronteira e permite estudar a sua diversidade histórica não só como diversidade estrutural de categorias sociais, mas também como diversidade social relativa aos diferentes modos e tempos de sua participação na história (MARTINS, 2009, p. 139).

É neste sentido que se percebe a concepção de fronteira que Bendo (Entrevista, nov. 2012) utiliza para discutir fronteira. Uma concepção percebida em um espaço contraditório de integração e conflito, que expressa as diferenças culturais, políticas e econômicas, produz uma sensação de distanciamento geográfico entre cidades vizinhas, estabelece diferenças entre "nós e eles". Martins explica:

[...] As forças produtivas se desenvolvem mais depressa do que as relações sociais; no capitalismo, a produçáo é social, masa apropriação dos resultados da produção é privada. Essa contradição fundamental anuncia o descompasso histórico entre o progresso material e o progresso social. A desigualdade do desenvolvimento se expressa nos desencontros que nos revelam diversidades, e não uniformidades da mesma realidade econômica e social ${ }^{17}$. (MARTINS, 2009, p. 80 grifos do autor).

A “desigualdade" do desenvolvimento expressa-se nos "desencontros" que revelam "diversidades" pela identidade. Para Claval (1999, p. 15), “a identidade aparece como uma construção cultural. Ela responde a uma necessidade existencial profunda, a de responder à questão: “quem sou eu?"”.No Paraguai, o aluno brasiguaio vivia como “[...] a maioria dos cidadãos não antepõe a luxúria liberal como objetivo impreterível e precípuo de vida. Mas, [...] à valorização daquilo que é material na medida das necessidades" (GOIRIS, 2010, p. 26).Pensa-se, neste sentido, que "a identidade deve ser analisada como um discurso que os grupos têm sobre eles mesmos e sobre os outros, para dar um sentido à sua existência" (CLAVAL, 1999, p. 14). Ao fazer-se referência também às culturas e às identidades, não se deveria pensá-las como sendo unificadas, mas como um discursoque concebe a diferença como integração ou identidade. (HALL, 2006).

A educação básica pelo seu currículo conduz à observação de identidades edificadas “[...] figuras que simbolizam uma unificação identitária e encobrem as mais variadas lutas e conflitos internos de grupos sociais [...]" (FREITAS, 2010, p 108), produzidos pelo sistema social e econômico capitalista. Esta visão de identidade faz parte da lógica do capital, contudo, a Educação tem papel preponderante para romper com essa lógica (MÉSZÁROS, 2008). Ao destacar a temporalidade própria de cada grupo, não só como diversidade estrutural, mas como diversidade social relativa aos diferentes modos e tempos da mesma realidade econômica e social, a escola pode iniciar um processopara romper a lógica a que se
17 Cf. Henri Lefebvre, La Pensée de Lénine, Paris, Bordas, 1957, esp. p. 206 e ss.

Geografia Ensino \& Pesquisa, v. 18, n.2, p. 77-96, maio/ago. 2014.

Frasson, M. 
${ }^{18}$ Deconcepções de fronteiras políticas e naturais,e concepções de fronteiras econômicas, étnicas culturais e sociais.
Geografia Ensino \& Pesquisa, v. 18, n.2, p. 77-96, maio/ago. 2014

Concepções e percepções de fronteiras dos Professores da

Educação Básica revelada por meio da foto-resposta (Extremo Oeste do Paraná - 2012) refere Mészáros.Isso também, ao mostrar limites e possibilidades no espaço ocupado pelo sujeito, em sua existência (econômica e social), utilizando-se das concepções de fronteiras econômicas, ética cultural e social permeadas no debate com os professores de Geografia.

As concepções de fronteiras,agrupadas em dois blocos ${ }^{18}$, permitiram, pela análise, evidenciar as possibilidades e limites ao realizar a leitura do espaço geográfico de fronteira para o sujeito, da Tríplice Fronteira (BR, PY e AR).

\section{Considerações finais}

A metodologia,uso da foto-resposta e entrevista em profundidade, permitiu que os professores manifestassem diferentes expressões de fronteira (cultural, da diversidade, do conhecimento, da metodologia, natural, religiosa, étnica, social, econômica, física, política, entre outras).

Fotografia e entrevista por meio do debate evidenciaram fronteiras e limites, que existem na escola pública da educação básica os quais, necessitam ser conhecidos etranspostos para construir uma educação que atenda ao aluno de fronteira (brasiguaio).

A concepção de fronteira empregada no trabalho pedagógico em sala de aula, a partir do currículo e livro didático, de acordo com os professores entrevistados, não é fronteira, é limite. No limite, não existe relação nem inter-relação. Ou seja, o currículo no contexto da sociedade neoliberal desenvolve uma educação para atender ao mercado. A forma como são tratadas as concepções acerca de seus conceitos coloca em relevo as condições que impedem o sujeito a perceber as fronteiras postas pelo sistema capitalista de produção ao seu desenvolvimento, limitando sua relação com o outros homens e como espaço.

As evidências postas pelo debate acerca da fronteiramostram necessidade de se pensar, pedagogicamente a dinâmica própria da região fronteiriça.Processo que inclui o atendimento às escolas de Educação Básica situadas em região de fronteira, visando idealizar e construir o sujeito histórico por meio de uma educação que possa gerar atitudes políticas, com possibilidades de intervir na realidade. Isso perpassa pelos conteúdos disciplinares ao trabalhar seus conceitos a partir de suas concepções.

Paraguai e Brasil, territórios nações dos alunos brasiguaios, constituem desde a década de 1990 fronteira de integração por fazerem parte do Bloco Econômico Mercosul. O Setor Educacional deste Bloco Econômico, o SEM,apresenta em seuPlano de Ação 2011/2015 “[...] políticas de formação docente" (MERCOSUL, 2011, p. 46,para instituições formadoras de seus países, cuja finalidade é o desenvolvimento econômico.

Esta pesquisapode ser uma reflexão necessária às Universidadespara definir seu posicionamento frente à complexidade da relação homem-mundo permeada pela relação homem-homem ao gerar a sociedade capitalista espacializada em contexto de fronteira.

Este artigo trouxe em seu contexto de discussão apenas cinco concepções de fronteira: Políticas Internacionais, Físicas (naturais), Econômicas, Étnico-culturais e Sociais.Suficientes para colocarem em relevo outras fronteiras percebidas no currículo, na educação formal, no livro didático, no ensino de Geografia e no espaço de fronteira. Isso comprova que a Geografia pode, através do ensino e da pesquisa, contribuir para pensar a educação e ensino de/na fronteira.

\section{Referências}

ARRUDA Aline Maria Thomé. Diferenciação e estereotipificação: libaneses na fronteira Brasil-Paraguai.Univ. Rel. Int., Brasilia, v. 5, n. 1/2, p. 43-65, jan./dez. 2007.

BOAL, Augusto. Teatro do oprimido e outas poéticas políticas. Rio de Janeiro: Civilização Brasileira, 1977. 
BOURDIEU, Pierre. O poder simbólico. Trad. Fernado de Tomaz. Lisboa: Difel. 1989.

CLAVAL, Paul. O território na transição da pós-modernidade. GEOgraphia, ano 1, n. 2, 1999.

COURLET, Claude. Globalização e fronteira. Ensaios FEE, Porto Alegre, v.17, n. 1, p. 11-22, 1996.

CREUZ, Luís Rodolfo Cruz e. A construção da defesa da concorrência no Mercosul: uma perspectiva construtivista - cooperação e interesses nas Relações internacionais. 2010. 210 p. Dissertação (Mestrado em Relações Internacionais) Universidade Estadual de Campinas, Instituto de Filosofia e Ciências Humanas. Campinas, 2010.

DIETZ, Circe Inês. Cenários contemporâneos da fronteira Brasil-Argentina: infra-estruturas estratégicas e o papel dos atores no processo de cooperação/integração transfronteiriça. 2008. 239 p. Dissertação (Mestrado em Geociências) Universidade Federal do Rio Grande do Sul, Instituto de Geociências, Porto Alegre, 2008.

DUARTE, Jorge. Entrevista em profundidade. Disponível em: <https://www.google.com.br/search?q=entrevista+e $\mathrm{m}+$ profundidade + jorge + duarte\&aq $=1 \& \mathrm{oq}=\mathrm{ENTREVISTA}+\mathrm{EM}+\mathrm{PRO \&}$ sugexp $=$ chrome, $\mathrm{mod}=9 \&$ sourceid $=\mathrm{chr}$ ome\&ie $=U T F-8>$. Acesso em 23/ago./2012.

FERRAZ, Cláudio B. O. Geografia: o olhar e a imagem pictórica. Revista Pro- Posições, Campinas, v. 20, n. 3 (60), p. 29-41, set/dez, 2009.

FERREIRA, N. S. C. Gestão democrática da educação: atuaistendências novos desafios. São Paulo: Cortez, 2003.

FRANCASTEL, Pierre. A realidade figurativa. São Paulo: Perspectiva, 1993.

FREITAS, Letícia Fonseca Richthofen de. Currículo cultural: o que ensinam os livros regionais sobre identidade? Currículo sem Fronteiras, v. 10, n. 2, p. 106-118, jul./dez. 2010.

GENTILI, Pablo. A falsificação do consenso: simulacro e imposição na reforma educacional do neoliberalismo. Petrópolis, RJ: Vozes, 1998.

GOIRIS, Fabio Anibal. O desconhecido como preceito: o caso do Paraguai. Revista Espaço Acadêmico, n. 112, p. 23-30, set. 2010.

GONCALVES, Leandro Forgiarini de. O estudo do lugar sob o enfoque da geografia humanista: um lugar chamado Avenida Paulista. 2010. 266 p. Dissertação (Mestrado em Geografia Humana) - Universidade de São Paulo, Faculdade de Filosofia, Letras e Ciências Humanas, São Paulo, 2010.

HALL, Stuart. A identidade cultural na pós-modernidade. Tradução Tomaz Tadeu da Silva, Guacira Lopes Louro. 11. ed. Rio de Janeiro: DP\&A, 2006.

HISSA, C. E. V. A mobilidade das fronteiras: inserções da geografia na crise da modernidade. Belo Horizonte: UFMG, 2006.

JACOMELI, Mara Regina Martins. Políticas para o Currículo Escolar: Significados e Implicações para a Escola. APASE. Ano 9, n. 24, out. 2008

KELSEN, Hans. Teoria pura do direito. Trad. João Baptista Machado. 6. ed. São Paulo : Martins Fontes, 1998.

KOSSOY, Boris. Construção e desmontagem. Revista USP, São Paulo, n. 62, p. 224-232, jun./ago. 2004.

. Fotografia \& história. São Paulo: Ateliê Editorial, 2003.

MACHADO, Lia Osório. Limites, fronteiras, Redes. In: STROHAECKER, A. et al (orgs.). Fronteiras e espaço global. Porto Alegre: AGB-Porto Alegre, 1998. p. 41-49.

MARTIN,Andre Roberto. Fronteiras e nações. 2. ed. São Paulo: Contexto, 1997.

MARTINS, Estevão de Resende. Cultura e poder. São Paulo: Saraiva, 2007.

MARTINS, José de Souza. Fronteira: a degradação do outro nos confins do humano. São Paulo: Contexto, 2009.

MERCOSUL. Plano de Ação do Setor Educacional do Mercosul: 2011- 2015. 1 sem 2011. Disponível em: <http:// www.sic.inep.gov.br/pt-BR/component/jdownloads/ finish/7/413.html>. Acesso em: 03 fev. 2013.

MÉSZÁROS, István. A Educação para além do capital. Tradução de Isa Tavares. São Paulo: Boitempo, 2008.

Geografia Ensino \& Pesquisa, v. 18, n.2, p. 77-96, maio/ago. 2014.

Frasson, M. Paulo: Boitempo, 2011. 
MINTO,Lalo Watanabe. Reforma do Estado e política educacional: o contexto para a reforma curricular em tempos neoliberais. APASE, ano 9, n. 24, out. 2008.

MONTIEL, Edgar. A nova ordem simbólica: a diversidade cultural na era da globalização. In: SIDEKUM, Antônio (org.). Alteridade e multiculturalismo. Ijuí: Unijuí, 2003.

MOREIRA, Ruy. Para onde vai o pensamento geográfico?: por uma epistemologia crítica. São Paulo: Contexto, 2006. 192p.

MOREIRA, Ruy. O discurso do avesso. Rio de Janeiro: Dois Pontos, 1987

NOGUEIRA, Ricardo José Batista. Fronteira: espaço de referência identitária? Revista Ateliê Geográfico, Goiânia, v. 1, n. 2, p. 27-41, dez. 2007.

OLIVEIRA, Verônica Macário de; MARTINS, Maria de Fátima; VASCONCELOS, Ana Cecília Feitosa. Entrevistas "em profundidade" na pesquisa qualitativa em administração: pistas teóricas e metodológicas. Disponível em: <Cesgranrio.org.br>. Acesso em: 27 dez. 2012.

OLIVEIRA JR, Wenceslao Machado de. Grafar o espaço, educar os olhos: rumo a geografias menores. Pro-Posições, Campinas, v. 20, n. 3 (60), p. 17-28, 2009.

RAFFESTIN, Claude. Por uma geografia do poder. São Paulo: Khedir Ed., 2011.

RUBIM, Sandra Regina Franchi; OLIVEIRA, Terezinha. A Imagem como fonte e objeto de pesquisa em História da Educação. In: SEMINÁRIO DE PESQUISA DO PPE, 2010, Maringá. Anais...Maringá, 2010.

SACRISTÁN, J. Gimeno; GÓMEZ, A. I. Perez. Compreender e transformar o ensino. Trad. Ernani F. da Fonseca Rosa. 4. ed. Porto Alegre: ArtMed, 1998.

SANTOS, Boaventura de Sousa. Modernidade, identidade e a cultura de fronteira.Tempo Social - Rev. Sociol. USP, São Paulo, v. 5, n. 1-2, p. 31-52, 1993.

SANTOS, Maria Elisa Pires.O cenário multilíngüe/multidialetal de fronteira e o processo identitário de alunos brasiguaios no contexto escolar. 2004. 253 p. Tese (Doutorado em Lingüística Aplicada) - Universidade Estadual de Campinas, Campinas, 2004.

SANTOS, Milton. A natureza do espaço: técnica e tempo, razão e emoção. 4. ed. São Paulo: Editora da Universidade de São Paulo, 2006.

SANTOS, Milton. Espaço e método. São Paulo: Nobel, 1985.

SANTOS, Milton. Metamorfoses do espaço habitado: fundamentos teóricos e metodológicos da geografia. 6. ed. São Paulo: EDUSP, 2008a.

SANTOS, Milton. Por uma outra globalização: do pensamento único à consciência universal. 16. ed. Rio de Janeiro: Record, 2008b.

VLACH, Vânia Rubia Farias. Fragmentos para uma discussão: método e conteúdo no ensino da geografia de $1 .^{\circ}$ e $2 .^{\circ}$ graus. Terra Livre, São Paulo, n. 2, p. 43-58, jul. 1987.

ENTREVISTAS (Entrevistas concedidas ao autor. Santa Terezinha de Itaipu, nov. 2012). Por: BENDO, Sebastiana Lopes de Miranda; BORGES, Ivan Gleison; FERREIRA, Maristela; FRANZES, Maria Noemia; GRIZ, Patrícia; IZÊE, Claudemery Pesseti; LUCCA, Rejane Egídia; MACIEL DO ROSÁRIO.; MOGERSTEARN, Lairce Terezinha Bosch; MOURA, Paulo Cezar de; OLIVEIRA, Beata Aparecida Reisdorferde; OLIVEIRA, Mireily Aparecida Tomazoli de.

Geografia Ensino \& Pesquisa, v. 18, n.2, p. 77-96, maio/ago. 2014

Concepções e percepções de fronteiras dos Professores da

Educação Básica revelada por meio da foto-resposta (Extremo Oeste do Paraná - 2012)

\section{Correspondência}

\section{Margarete Frasson}

E-mail: marga.sti@hotmail.com

Recebido em 12 de novembro de 2013.

Aceito para publicação em 05 de agosto de 2014. 